\title{
Fatty Acid Synthase Inhibitors Isolated from Punica granatum L.
}

\author{
He-Zhong Jiang, ${ }^{a, c}$ Qing-Yun Ma, ${ }^{a}$ Hui-Jin Fan, ${ }^{b}$ Wen-Juan Liang, ${ }^{a}$ Sheng-Zhuo Huang, ${ }^{a}$ \\ Hao-Fu Dai, ${ }^{a}$ Peng-Cheng Wang, ${ }^{a}$ Xiao-Feng Ma ${ }^{*, b}$ and You-Xing Zhao*,a
}

${ }^{a}$ Institute of Tropical Bioscience and Biotechnology, Chinese Academy of Tropical Agricultural

Sciences, Haikou 571101, People's Republic of China

${ }^{b}$ College of Life Sciences, Graduate University of Chinese Academy of Sciences, Beijing 100049, People's Republic of China

${ }^{c}$ School of Life Science and Engineering, Southwest Jiaotong University, Chengdu 610031, People's Republic of China

\begin{abstract}
Este trabalho tem por objetivo o isolamento de inibidores da enzima ácido graxo sintase (FAS) a partir de acetato de etila proveniente de extratos de cascas de frutas da Punica granatum L. A investigação química guiada por bioensaios das cascas das frutas resultou no isolamento de dezessete compostos incluindo principalmente triternóides e compostos fenólicos, dos quais um novo triterpeno do tipo oleanano (punicaone) juntamente com quatorze compostos conhecidos foram isolados pela primeira vez a partir desta planta. Sete dos componentes isolados foram avaliados para atividades inibitórias de FAS e dois deles apresentaram-se ativos. Em particular, o ácido flavogalônico que exibiu forte atividade inibitória de FAS com valor de $\mathrm{IC}_{50}$ de 10,3 $\mu \mathrm{mol} \mathrm{\textrm {L } ^ { - 1 }}$.

The aim of this work is the isolation of fatty acid synthase (FAS) inhibitors from the ethyl acetate extracts of fruit peels of Punica granatum L. Bioassay-guided chemical investigation of the fruit peels resulted in the isolation of seventeen compounds mainly including triterpenoids and phenolic compounds, from which one new oleanane-type triterpene (punicaone) along with fourteen known compounds were isolated for the first time from this plant. Seven isolates were evaluated for inhibitory activities of FAS and two compounds showed to be active. Particularly, flavogallonic acid exhibited strong FAS inhibitory activity with $\mathrm{IC}_{50}$ value of $10.3 \mu \mathrm{mol} \mathrm{L}{ }^{-1}$.
\end{abstract}

Keywords: fatty acid synthase (FAS), Punica granatum, flavogallonic acid, punicaone

\section{Introduction}

The animal fatty acid synthase (FAS; EC 2.3.1.85) is a key metabolic enzyme catalyzing the de novo synthesis of long chain saturated fatty acids from acetyl-CoA and malonyl-CoA in the presence of the reducing substrate NADPH (nicotinamide adenine dinucleotide phosphate). ${ }^{1}$ A number of studies has recently reported that FAS may be a potential target for anti-obesity and anti-cancer drugs. ${ }^{2-5}$ At the same time, many FAS inhibitors, such as cerulenin, C75, orlistat and EGCG (epigallocatechin gallate), have joint effects of weight-loss and anti-tumor. ${ }^{6,7}$ These prove that FAS may be a clinical and experimental target for scientific research and drug discovery. In other words, natural products inhibiting FAS are appearing as potential

*e-mail: zhaoyx1011@163.com, maxiaofeng@gucas.ac.cn therapeutic agents to treat cancer and obesity. Therefore, it is important to find novel compounds especially from natural sources that reduce FAS activity or expressing levels that may be useful for the treatment of obesity and cancer.

During our early screening of activity, the ethanol extract of the peels of Punica granatum L. (family Punicaceae) showed strong capability of inactivating FAS with the $\mathrm{IC}_{50}$ (half maximal inhibitory concentration) value at $2.27 \mu \mathrm{g} \mathrm{mL}^{-1}$. P. granatum is a shrub and is mainly distributed in North America, the Mediterranean region and the Western part of Asia. ${ }^{8}$ In China, this shrub is cultivated and its pericarp is used medicinally for the treatment of colitis, diarrhea, dysentery, leucorrhea, menorrhagia, oxyuriasis and paralysis. ${ }^{8,9}$ The other parts of this plant, such as roots, leaves, flowers and seeds, are also employed for various therapeutic purposes. ${ }^{10}$ The major constituents of peels were found to be flavonoids, tannins and triterpenes. ${ }^{8}$ Despite a number of 
studies on the chemical constituents and biological activities of P. granatum, none of them investigates its FAS inhibitory activity. In order to screen FAS inhibitors, 17 compounds (Figure 1) were isolated from peels of $P$. granatum by column chromatography and identified as punicaone (1), oleanic acid (2), 13-hydroxy-3-keto-olean-12-en-28-oic acid (3), lantanolic acid (4), lantic acid (5), 33,24-dihydroxyurs12-en-28-oic acid (6), lupeol (7), betulinic acid (8), betulin (9), friedelin (10), sesamin (11), 4-hydroxy sesamin (12), gallic acid (13), 8-(3, 5-dihydroxyphenyl)-1-propyloctyl 2, 4-dihydroxy-6-undecylbenzoate (14), $\beta$-sitosteryl acetate (15), borneol (16) and flavogallonic acid (17) by MS (mass spectrometry) and NMR (nuclear magnetic resonance) data analyses. Comparing data with literature, compound 1 (25-hydroxy-3-oxoolean-1,12-dien-28-oic acid) is a new oleanane-type triterpene (named punicaone). This compound 1 together with 3-12 and 14-17 were isolated for the first time from Punica granatum, and seven of these compounds were assayed for FAS inhibitory activities. Compound $\mathbf{1 7}$ presented significant inhibition of FAS activity with the lowest $\mathrm{IC}_{50}$ value $\left(10.3 \mu \mathrm{mol} \mathrm{L} \mathrm{L}^{-1}\right)$. Herein, it is reported the isolation of these 17 compounds, the structural elucidation of the new compound (punicaone, 1) and the FAS inhibitory activities of some isolates.

\section{Experimental}

\section{General procedures}

Optical rotations were measured on a Horiba SEPA-300 polarimeter. UV spectra were obtained on a Shimadzu double-beam $210 \mathrm{~A}$ spectrometer. Infrared (IR) spectra were obtained on a Tensor 27 spectrometer with $\mathrm{KBr}$ pellets. NMR spectra were recorded on Bruker AV-400 or DRX-500 spectrometer with TMS (tetramethylsilane) as an internal standard using $\mathrm{CDCl}_{3}$ as solvent. Electrospray ionization mass spectrometry (ESI-MS) and high-resolution-ESI-MS were recorded with an API QSTAR Pulsar 1 spectrometer. Silica gel (200-300 mesh, Qingdao Marine Chemical Inc., People's Republic of China), RP-18 (40-70 $\mu \mathrm{m}$, Fuji Silysia Chemical Ltd., Japan) and Sephadex LH-20 (Amersham Biosciences, Sweden) were used for column chromatography. Fractions were monitored by TLC (thin layer chromatography) and spots were visualized by heating after spraying with $10 \% \mathrm{H}_{2} \mathrm{SO}_{4}$ in ethanol.

\section{Plant material}

The peels of Punica granatum were purchased from a market in Kunming (People's Republic of China) and identified by Prof. Li Gong Lei from Kunming Institute of Botany, Chinese Academy of Sciences. The specimen (JHZ20081201) was deposited at the State Key Laboratory of Phytochemistry and Plant Resources in West China from Kunming Institute of Botany, Chinese Academy of Sciences.

\section{Extraction and isolation}

The air-dried and powdered peels of Punica granatum $\mathrm{L}$. $(10.5 \mathrm{~kg})$ were extracted with $95 \% \mathrm{EtOH}$ under reflux for three times $(3 \times 10 \mathrm{~L})$. The extract was concentrated and suspended in water followed by successive partition with petroleum ether $(3 \times 5 \mathrm{~L})$, EtOAc $(3 \times 5 \mathrm{~L})$, and $n-\mathrm{BuOH}(3 \times 5 \mathrm{~L})$ to yield petroleum ether soluble $(18.5 \mathrm{~g})$, EtOAc-soluble $(835.0 \mathrm{~g})$ and $n$-BuOH-soluble $(126.5 \mathrm{~g})$ fractions, respectively. A portion $(427.8 \mathrm{~g})$ of the EtOAc extract was separated by silica gel column (200-300 mesh) using a gradient solvent system of petroleum ether/acetone (10:1-0:1) to afford fractions A-D. Fraction A (48 g) was separated by silica gel column using a gradient solvent system of petroleum ether/acetone (15:1-2:1) to afford fractions A1-A7 according to their TLC pattern. Fraction A2 (17.6 g) was repeated gel filtrated on Sephadex LH-20 $\left(\mathrm{CHCl}_{3} / \mathrm{MeOH} 1: 1\right)$ to yield compounds $\mathbf{1 5}(38 \mathrm{mg}), \mathbf{9}(5 \mathrm{mg}), \mathbf{1 0}(3 \mathrm{mg}), \mathbf{8}(10 \mathrm{mg}), \mathbf{7}(28 \mathrm{mg})$ and $16(8 \mathrm{mg})$. Compounds $2(64 \mathrm{mg}), \mathbf{4}(4 \mathrm{mg})$ and $6(11 \mathrm{mg})$ were isolated from fractions A5 (2.4 g) by Sephadex LH-20 column chromatography with $\mathrm{CHCl}_{3} / \mathrm{MeOH}(1: 1)$ as solvent. Compounds $\mathbf{1 2}(6 \mathrm{mg}), \mathbf{3}(27 \mathrm{mg}), \mathbf{1}(5 \mathrm{mg})$ and $\mathbf{1 4}(6 \mathrm{mg})$ were obtained from sub-fraction A6 (3.8 g) by repeated silica gel column chromatography with petroleum ether/acetone (8:1-1:1), RP-18 column eluted with $\mathrm{MeOH}-\mathrm{H}_{2} \mathrm{O}$ gradient system (30-70\%) and then chromatographed over Sephadex LH-20 column, using $\mathrm{CHCl}_{3}-\mathrm{MeOH}$ (1:1) as solvent. Fraction B (26.5 g) was separated by silica gel column using a gradient solvent system of petroleum ether/acetone (10:1-1:1) to afford fractions B1-B4. The sub-fractions B2 was then chromatographed on Sephadex LH-20 $\left(\mathrm{CHCl}_{3} / \mathrm{MeOH} 1: 1\right)$ to yield compound $\mathbf{1 1}(5 \mathrm{mg})$. Fraction C (307 g) was separated on a silica gel column using a gradient of petroleum ether/acetone $(4: 1-1: 1)$ to yield nine fractions (C1-C9). The fraction C3 (1.7 g) was submitted to Sephadex LH-20 $\left(\mathrm{CHCl}_{3} / \mathrm{MeOH} 1: 1\right)$ to yield compounds 5 (7 mg), 13 (81 $\mathrm{mg})$ and $\mathbf{1 7}(28 \mathrm{mg})$.

\section{Punicaone (1)}

Yellow oil; $[\alpha]_{\mathrm{D}}^{20.7}+47.0^{\circ}\left(c 0.200, \mathrm{CH}_{3} \mathrm{OH}\right)$; UV $\left(\mathrm{CH}_{3} \mathrm{OH}\right) \lambda_{\max } / \mathrm{nm}(\log \varepsilon) 203$ (3.834), 217 (3.812), 379 (2.100); IR (KBr) $v_{\max } / \mathrm{cm}^{-1} 3432,2931,1688,1461,1382$; EI-MS m/z (\%) $468\left[\right.$ [M] $^{+}(5), 423$ (15), 395 (16), 259 (25), 248 (29), 203 (59), 135 (76), 95 (81), 81 (100); HR-EI-MS $\mathrm{m} / \mathrm{z}(\%): 468.3250[\mathrm{M}]^{+}\left(\right.$calcd. for $\left.\mathrm{C}_{30} \mathrm{H}_{44} \mathrm{O}_{4}, 468.3240\right)$; 


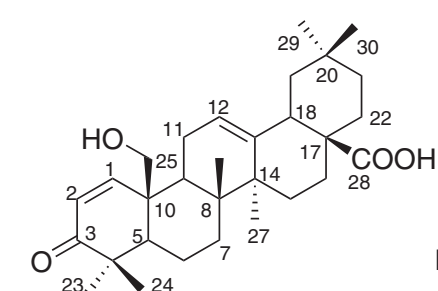

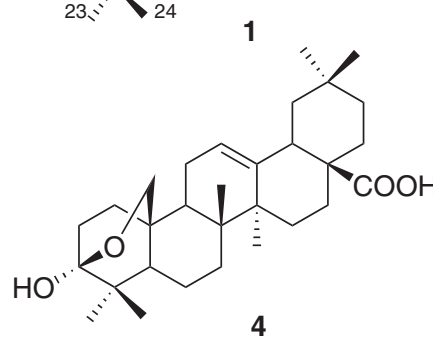

4

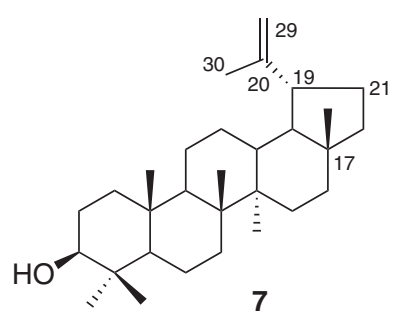

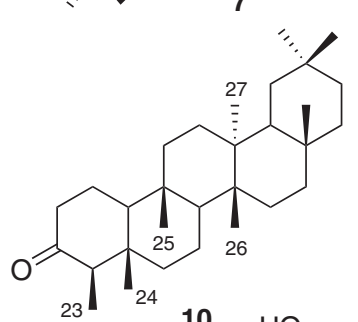<smiles>O=C(O)c1cc(O)c(O)c(O)c1</smiles>

13<smiles>CC1(C)CCC2(C(=O)O)CC[C@H]3C4=CCC5C6(C)CC[C@@H](O)C(C)(C)C6CC[C@]5(C)C4CCC3C2C1</smiles>

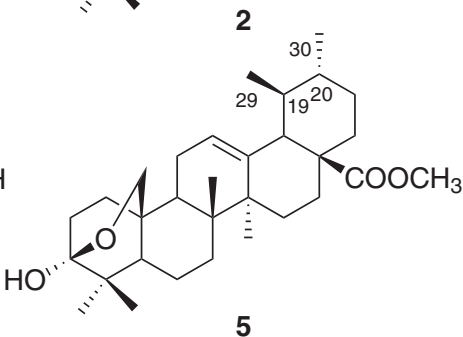

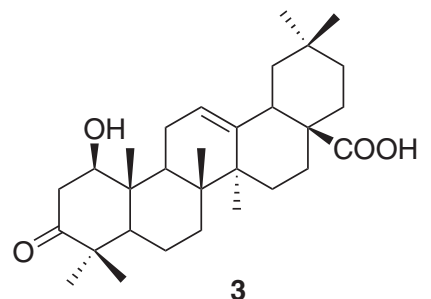

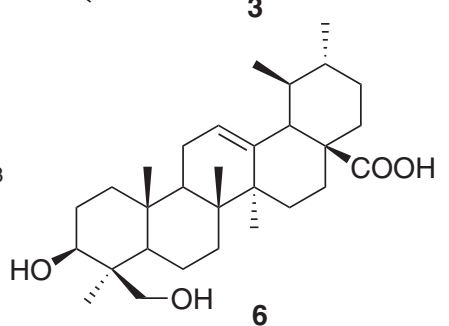<smiles>C=C(C)C1CCC2(C(=O)O)CCC3C(CCC4C3(C)CCC3C(C)(C)C(O)CCC34C)C12</smiles><smiles>C=C(C)C1CCC2(CO)CC[C@H]3C(CCC4C3CC[C@@]3(C)[C@@H](C)[C@@H](O)CCC43C)C12</smiles><smiles>c1cc2c(cc1[C@H]1OC[C@H]3O[C@H](c4ccc5c(c4)OCO5)OC[C@@H]31)OCO2</smiles><smiles>OC1O[C@@H](c2ccc3c(c2)OCO3)C2CO[C@H](c3ccc4c(c3)OCO4)[C@H]12</smiles>

11

12

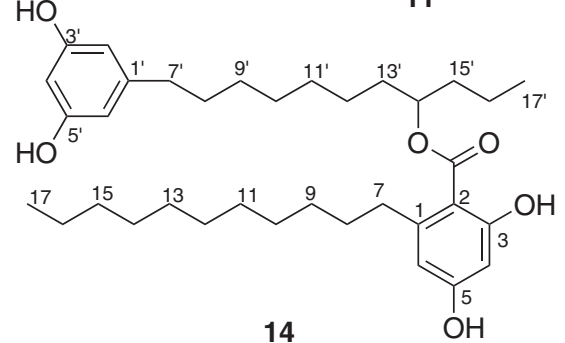

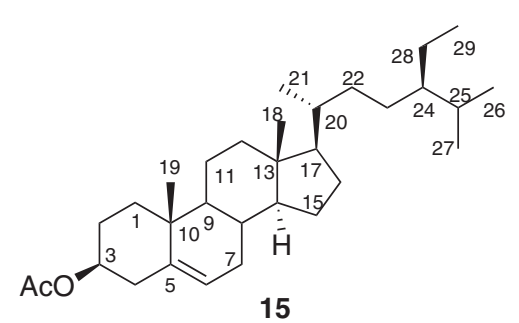<smiles>CC1CCCCC1O</smiles>

16<smiles>O=C1Oc2c(O)c(O)c(-c3c(O)c(O)cc(O)c3O)c3c2c(=O)oc2c(O)c(O)cc1c23</smiles>

17

Figure 1. Chemical structures of compounds 1-17.

${ }^{1} \mathrm{H}$ NMR (400 MHz, $\mathrm{CDCl}_{3}$ ) and ${ }^{13} \mathrm{C}$ NMR (100 MHz, $\mathrm{CDCl}_{3}$ ) see Table 1 .

FAS inhibitory activity assays

The preparation, storage and usage of FAS from chicken liver, which shares $63 \%$ identity with the amino acid sequence of human FAS, were performed as previously described in literatures. ${ }^{15}$ FAS activity was measured at $37^{\circ} \mathrm{C}$ by the changes of NADPH absorption at $340 \mathrm{~nm}$ with a UV-Visible spectrophotometer (Amersham Pharmacia Ultrospec 4300, England, UK). The reaction mixture contained $100 \mathrm{mmol} \mathrm{L}-1 \mathrm{KH}_{2} \mathrm{PO}_{4}-\mathrm{K}_{2} \mathrm{HPO}_{4}$ buffer $\mathrm{pH}$ 7.0, $1 \mathrm{mmol} \mathrm{L}^{-1}$ EDTA, $1 \mathrm{mmol}^{-1} \mathrm{~L}$ dithiothreitol, $3 \mu \mathrm{mol} \mathrm{L}^{-1}$ 
Table 1. ${ }^{1} \mathrm{H}$ and ${ }^{13} \mathrm{C}$ NMR data of $\mathbf{1}$ in $\mathrm{CD}_{3} \mathrm{OD}$

\begin{tabular}{|c|c|c|}
\hline No. & $\delta{ }^{13} \mathrm{C}$ & $\delta{ }^{1} \mathrm{H}$ \\
\hline 1 & 150.7, d & $6.35, \mathrm{~d}, 1 \mathrm{H}, J 10.2 \mathrm{~Hz}$ \\
\hline 2 & 128.1, d & $5.88, \mathrm{~d}, 1 \mathrm{H}, J 10.2 \mathrm{~Hz}$ \\
\hline 3 & 206.0, s & \\
\hline 4 & $42.0, \mathrm{~s}$ & \\
\hline 5 & $44.0, \mathrm{~d}$ & $1.84, \mathrm{t}, 1 \mathrm{H}, J 8.0 \mathrm{~Hz}$ \\
\hline 6 & $18.9, \mathrm{t}$ & $1.50, \mathrm{~m}, 2 \mathrm{H}$ \\
\hline 7 & $32.4, \mathrm{t}$ & $1.80,1.58, \mathrm{~m}, 2 \mathrm{H}$ \\
\hline 8 & $39.6, \mathrm{~s}$ & \\
\hline 9 & $38.2, \mathrm{~d}$ & $2.23, \mathrm{dd}, 1 \mathrm{H}, J 11.2,5.6 \mathrm{~Hz}$ \\
\hline 10 & $47.7, \mathrm{~s}$ & \\
\hline 11 & $26.0, \mathrm{t}$ & $2.67,2.63, \mathrm{~m}, 2 \mathrm{H}$ \\
\hline 12 & 123.7, d & $5.35, \mathrm{~m}, 1 \mathrm{H}$ \\
\hline 13 & $141.9, \mathrm{~s}$ & \\
\hline 14 & $41.4, \mathrm{~s}$ & \\
\hline 15 & $27.6, \mathrm{t}$ & $1.68,1.12, \mathrm{~m}, 2 \mathrm{H}$ \\
\hline 16 & $23.0, \mathrm{t}$ & $1.50,0.95, \mathrm{~m}, 2 \mathrm{H}$ \\
\hline 17 & $46.8, \mathrm{~s}$ & \\
\hline 18 & $41.7, \mathrm{~d}$ & $2.86, \mathrm{~m}, 1 \mathrm{H}$ \\
\hline 19 & $45.3, \mathrm{t}$ & $1.64,1.22, \mathrm{~m}, 2 \mathrm{H}$ \\
\hline 20 & $30.6, \mathrm{~s}$ & \\
\hline 21 & $33.8, \mathrm{t}$ & $1.36,1.24, \mathrm{~m}, 2 \mathrm{H}$ \\
\hline 22 & $31.9, \mathrm{t}$ & $1.50,1.37, \mathrm{~m}, 2 \mathrm{H}$ \\
\hline 23 & $25.5, \mathrm{q}$ & $1.19, \mathrm{~s}, 3 \mathrm{H}$ \\
\hline 24 & $16.2, \mathrm{q}$ & $1.28, \mathrm{~s}, 3 \mathrm{H}$ \\
\hline 25 & $69.4, \mathrm{t}$ & $3.47, \mathrm{~d}, 1 \mathrm{H}, J 10.9 \mathrm{~Hz} ; 3.36, \mathrm{~d}, 1 \mathrm{H}, J 10.9 \mathrm{~Hz}$ \\
\hline 26 & $17.3, \mathrm{q}$ & $1.05, \mathrm{~s}, 3 \mathrm{H}$ \\
\hline 27 & $23.5, \mathrm{q}$ & $0.94, \mathrm{~s}, 3 \mathrm{H}$ \\
\hline 28 & 183.1, s & \\
\hline 29 & $33.0, \mathrm{q}$ & $0.91, \mathrm{~s}, 3 \mathrm{H}$ \\
\hline 30 & $17.9, \mathrm{q}$ & $0.89, \mathrm{~s}, 3 \mathrm{H}$ \\
\hline
\end{tabular}

acetyl-CoA, $10 \mu \mathrm{mol} \mathrm{L}{ }^{-1}$ malonyl-CoA, $35 \mu \mathrm{mol} \mathrm{L}{ }^{-1}$ NADPH and $10 \mu \mathrm{g}$ FAS, totalizing a volume of $2 \mathrm{ml}$. The preparative concentrations of FAS and its substrate were spectrophotometrically determined with the following extinction coefficients: FAS $4.83 \times 105 \mathrm{~mol}^{-1} \mathrm{~L} \mathrm{~cm}^{-1}$ at $279 \mathrm{~nm}$, acetyl-CoA $1.54 \times 104 \mathrm{~mol}^{-1} \mathrm{~L} \mathrm{~cm}^{-1}$ at $259 \mathrm{~nm}$ $\mathrm{pH} 7.0$, malonyl-CoA $1.46 \times 104 \mathrm{~mol}^{-1} \mathrm{~L} \mathrm{~cm}^{-1}$ at $260 \mathrm{~nm}$ and $\mathrm{pH}$ 6.0, acetoacetyl-CoA $1.59 \times 104 \mathrm{~mol}^{-1} \mathrm{~L} \mathrm{~cm}^{-1}$ at $259 \mathrm{~nm}$ and $\mathrm{pH} 7.0$, NADPH $6.02 \times 103 \mathrm{~mol}^{-1} \mathrm{~L} \mathrm{~cm}^{-1}$ at $340 \mathrm{~nm}$ and $1.59 \times 104 \mathrm{~mol}^{-1} \mathrm{~L} \mathrm{~cm}^{-1}$ at $259 \mathrm{~nm}$ and $\mathrm{pH} 9.0$.

\section{Results and Discussion}

Compound $\mathbf{1}$ was obtained as a yellow oil and had the molecular formula $\mathrm{C}_{30} \mathrm{H}_{44} \mathrm{O}_{4}$ determined by HR-EI-MS
( $m / z$ 468.3250, calcd. for $\mathrm{C}_{30} \mathrm{H}_{44} \mathrm{O}_{4}: 468.3240$ ). The IR spectrum showed absorption bands at 3432, 2931, 1722, $1688,1640,1461$ and $1382 \mathrm{~cm}^{-1}$, which were indicative of hydroxyl groups, carbonyls and double bonds. The ${ }^{1} \mathrm{H}$ and ${ }^{13} \mathrm{C}$ NMR spectra (Table 1) displayed 30 carbon resonances comprising six methyl groups, nine methylenes (including one oxygenated at $\delta_{\mathrm{C}} 69.4$ ), six methines (including three olefinic at $\delta_{\mathrm{C}} 150.7,128.1$ and 123.7), nine quaternary carbons (one carbonyl at 206.0, one carboxyl at 183.1 and one olefinic at 141.9), suggesting that compound 1 owns a typical oleanane skeleton. ${ }^{11,12}$ The NMR data of $\mathbf{1}$ were similar to that of amooranin..$^{13,14}$ However, different carbon and proton chemical shifts for C-1, C-2 and C-3 indicated that the structure of $\mathbf{1}$ differed from amooranin. In the ${ }^{13} \mathrm{C}$ NMR spectrum of $\mathbf{1}$, signals of two methylenes disappeared, and new signals occurred for two olefinic methines. The HMBC (heteronuclear multiple-bond correlation spectroscopy) spectrum (Figure 2) displayed distinct correlations from $\mathrm{H}-2\left[\delta_{\mathrm{H}} 5.88(\mathrm{~d}, 1 \mathrm{H}, J 10.2 \mathrm{~Hz})\right]$ to $\mathrm{C}-4\left(\delta_{\mathrm{C}} 42.0\right), \mathrm{H}-1\left[\delta_{\mathrm{H}} 6.35(\mathrm{~d}, 1 \mathrm{H}, J 10.2 \mathrm{~Hz})\right]$ to $\mathrm{C}-5$ $\left(\delta_{\mathrm{C}} 44.0\right)$, and C-3 $\left(\delta_{\mathrm{C}} 206.0\right), \mathrm{H}-25\left[\delta_{\mathrm{H}} 3.47(\mathrm{~d}, 1 \mathrm{H}\right.$, $J 10.2 \mathrm{~Hz})$ and $3.36(\mathrm{~d}, 1 \mathrm{H}, J 10.2 \mathrm{~Hz})]$ to $\mathrm{C}-1\left(\delta_{\mathrm{C}} 150.7\right)$ and C-5 $\left(\delta_{\mathrm{C}} 44.0\right)$, indicating the presence of conjugated two olefinic methines and carbonyl on ring A. By analysis of the 1D and 2D NMR data and comparison with literature, ${ }^{11-14}$ compound $\mathbf{1}$ was identified as 25-hydroxy-3-oxoolean1,12-dien-28-oic acid, named punicaone.

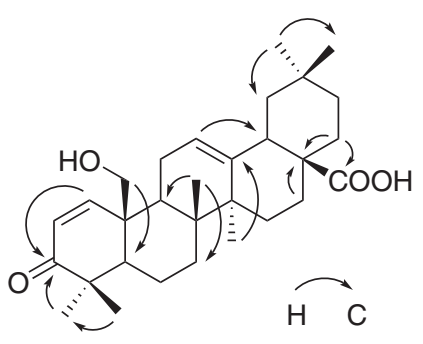

Figure 2. Key HMBC correlations of compound $\mathbf{1}$.

The FAS inhibitory activity of compounds $\mathbf{2}, \mathbf{3}, \mathbf{7}$, 12-14 and 17 was determined by previous described method..$^{15}$ The results are presented in Table 2. The known FAS inhibitor EGCG ( $\mathrm{IC}_{50}$ of $51.97 \mu \mathrm{mol} \mathrm{L} \mathrm{L}^{-1}$ ) was used as positive control in this assay. Compounds 2 (oleane-type triterpene) and $\mathbf{1 7}$ (gallogen-type phenols) exhibited strong inhibitory activity with the lowest $\mathrm{IC}_{50}$

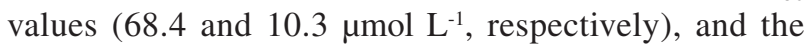
other five compounds showed weak activity. Oleanetype triterpene and its oligoglycosides from the hulls of Nephelium lappaceum L. were found to have effective FAS inhibitions. ${ }^{16}$ The gallogen-type phenols could also be considered as another type of natural FAS inhibitors based on this test. 
Table 2. The inhibitory activity of the compounds isolated from Punica granatum $\mathrm{L}$. against FAS ${ }^{\text {a }}$

\begin{tabular}{lc}
\hline Compound & FAS inhibitory activity $\left(\mathrm{IC}_{50} / \mu \mathrm{mol} \mathrm{L}^{-1}\right)$ \\
\hline $\mathbf{2}$ & $68.4 \pm 0.8$ \\
$\mathbf{3}$ & $>200^{\mathrm{b}}$ \\
$\mathbf{7}$ & $>200^{\mathrm{b}}$ \\
$\mathbf{1 2}$ & $>200^{\mathrm{b}}$ \\
$\mathbf{1 3}$ & $>200^{\mathrm{b}}$ \\
$\mathbf{1 4}$ & $>200^{\mathrm{b}}$ \\
$\mathbf{1 7}$ & $10.3 \pm 0.3$ \\
$\mathrm{EGCG}^{\mathrm{c}}$ & $52 \pm 2$ \\
\hline
\end{tabular}

${ }^{\mathrm{a}} \mathrm{C}_{50}$ values were determined by regression analyses and expressed as mean \pm standard deviation for three distinct experiments; ${ }^{b} \mathrm{IC}_{50}$ values over $200 \mu \mathrm{mol} \mathrm{L}^{-1}$ are considered weak inhibitory FAS activity; 'positive controls.

\section{Conclusion}

In this work, 17 FAS inhibitor compounds were isolated from peels of $P$. granatum by column chromatography and identified through structural elucidation. Compound 1 (25-hydroxy-3-oxoolean-1,12-dien-28-oic acid) is a new oleanane-type triterpene (named punicaone). Compounds 1, 3-12 and 14-17 were isolated for the first time from Punica granatum, and seven of them were assayed for FAS inhibitory activities. Between the six isolates, compound $\mathbf{1 7}$ presented the lowest $\mathrm{IC}_{50}$ value $\left(10.3 \mu \mathrm{mol} \mathrm{L}^{-1}\right)$ concerning the inhibition of FAS activity.

\section{Supplementary Information}

Supplementary data (NMR spectra of the new compound) are available free of charge at http://jbcs.sbq.org.br as PDF file.

\section{Acknowledgements}

This work was supported by the Natural Science foundation of Hainan (211020) and Yunnan (2008CD159), the National Nonprofit Institute Research Grant of CATAS-ITBB (110301) and the Fundamental Research
Funds for the Central Universities (No. SWJTU11BR073, SWJTU11ZT26). The authors are thankful to the members of the analytical group of the State Key Laboratory of Phytochemistry and Plant Resources in West China, Kunming Institute of Botany, for the spectral measurements.

\section{References}

1. Wakil, S. J.; Biochemistry 1989, 28, 4523.

2. Menendez, J.A.; Lupu, R.; Colomer, R.; Mol. Genet. Metab. 2005, 84, 293.

3. Loftus, T. M.; Jaworsky, D. E.; Frehywot, G. L.; Townsend, C.A.; Ronnett, G. V.; Lane, M. D.; Kuhajda, F. P.; Science 2000, $288,2379$.

4. Li, X. H.; Hou, Y. T.; Acta Biochim. Biophys. Sin. 2003, 35, 1.

5. Kuhajda, F. P.; Cancer Res. 2006, 66, 5977.

6. Pizer, E. S.; Wood, F. D.; Pasternack, G. R.; Kuhajda, F. P.; Cancer Res. 1996, 56, 745.

7. Kuhajda, F. P.; Pizer, E. S.; Li, J. N.; Mani, N. S.; Frehywot, G. L.; Townsend, C. A.; Proc. Natl. Acad. Sci. U. S. A. 2000, 97, 3450.

8. Lansky, E. P.; Newman, R. A.; J. Ethnopharmacol. 2007, 109, 177.

9. Wang, R. F.; Xie, W. D.; Zhang, Z.; Ding, Y.; Wang, W.; Ma, C.; Du, L. J.; J. Nat. Prod. 2004, 67, 2096.

10. Li, H. X.; Wang, Z.; Liu, Y. Z.; Chinese Traditional and Herbal Drugs 2002, 33, 765.

11. Salem, M. M.; Werbovetz, K. A.; J. Nat. Prod. 2006, 69, 43.

12. Maillard, M.; Adewunmi, C. O.; Hostettmann, K.; Phytochemistry 1992, 31, 1321.

13. Rabi, T.; Curr. Sci. 1996, 70, 80.

14. Singh, S. K.; Singh, A.; Tripathi, V. J.; Finzi, P. V.; J. Indian Chem. Soc. 1996, 73, 547.

15. Jiang, H. Z.; Quan, X. F.; Tian, W. X.; Hu, J. M.; Wang, P. C.; Huang, S. Z.; Cheng, Z. Q.; Liang, W. J.; Zhou, J.; Ma, X. F.; Zhao, Y. X.; Bioorg. Med. Chem. Lett. 2010, 20, 6045.

16. Zhao, Y. X.; Liang, W. J.; Fan, H. J.; Ma, Q. Y.; Tian, W. X.; Dai, H. F.; Jiang, H. Z.; Li, N.; Ma, X. F.; Carbohydr. Res. 2011, 346, 1302.

Submitted: November 19, 2011 Published online: April 17, 2012 